\title{
Multispecies Weed Competition and Their Economic Threshold ON THE WHEAT CROP ${ }^{1}$
}

\author{
Interferência e Nível de Dano Econômico de Várias Espécies Infestantes na Cultura de Trigo
}

\author{
GHEREKHLOO, J. ${ }^{2}$, NOROOZI, S. ${ }^{3}$, MAZAHERI, D. ${ }^{3}$, GHANBARI, A. ${ }^{4}$, GHANNADHA, M.R. ${ }^{3}$, \\ VIDAL, R.A. ${ }^{5}$ and DE PRADO, R. ${ }^{6}$
}

\begin{abstract}
Two field experiments were conducted to evaluate the effects of multispecies weed competition on wheat grain yield and to determine their economic threshold on the crop. The experiments were conducted in 2002, on two sites in Iran: at the Agricultural Research Station on Ferdowsi University of Mashhad (E1) and on the fields of Shirvan's Agricultural College (E2). A $15 \times 50$ m area of a 15 ha wheat field in E1 and a $15 \times 50$ m area of a 28 ha wheat field in E2 were selected as experimental sites. These areas were managed like other parts of the fields, except for the use of herbicides. At the beginning of the shooting stage, 30 points were randomly selected by dropping a $50 \times 50 \mathrm{~cm}$ square marker on each site. The weeds present in E1 were: Avena ludoviciana, Chenopodium album, Solanum nigrum, Stellaria holostea, Convolvulus spp., Fumaria spp., Sonchus spp., and Polygonum aviculare. In E2 the weeds were A. ludoviciana, Erysimum sp., P. aviculare, Rapistrum rugosum, C. album, Salsola kali, and Sonchus sp. The data obtained within the sampled squares were submitted to regression equations and weeds densities were calculated in terms of TCL (Total Competitive Load). The regression analysis model indicated that only A. ludoviciana, Convolvulus spp. and C. album, in E1; and A. ludoviciana, S. kali, and R. rugosum, in E2 had a significant effect on the wheat yield reduction. Weed economic thresholds were 5.23 TCL in E1 and 6.16 TCL in E2; which were equivalent to 5 plants $\mathrm{m}^{-2}$ of A. ludoviciana or 12 plants $\mathrm{m}^{-2}$ of Convolvulus spp. or 19 plants $\mathrm{m}^{-2}$ of C. album in E1; and 6 plants $\mathrm{m}^{-2}$ A. ludoviciana, 13 plants $\mathrm{m}^{-2}$ S. kali and 27 plants $\mathrm{m}^{-2}$ R. rugosum in E2. Simulations of economic weed thresholds using several wheat grain prices and weed control costs allowed a better comparison of the experiments, suggesting that a more competitive crop at location E1 than at E2 was the cause of a lower weed competitive ability at the first location.
\end{abstract}

Keywords: weed interference, competition, grain yield, mathematical regression.

RESUMO - Foram realizados dois experimentos para avaliar os efeitos da interferência de várias espécies daninhas sobre a produtividade e rendimento de trigo e determinar o seu nivel de dano econômico (NDE) sobre a cultura. Os experimentos foram conduzidos em 2002, em dois locais no Irã: na Estação de Pesquisa Agricola (EPA) da Universidade Ferdowsi, Mashhad (E1) e na EPA do Agricultural College, Shirvan (E2). Numa lavoura de trigo de 15 e 28 ha, nas Epa localizadas em E1 e E2, respectivamente, selecionaram-se áreas de $15 \times 50 \mathrm{~m}$ como local dos experimentos. Estas áreas foram manejadas como outras partes do campo, exceto para o uso de herbicidas. No início do estádio de espigamento foram sorteados 30 pontos de coleta de $50 \times 50 \mathrm{~cm}$ em cada local. As plantas daninhas presentes em E1 foram: Avena ludoviciana, Chenopodium album, Solanum nigrum, Stellaria holostea, Convolvulus spp., Fumaria spp., Sonchus spp., e Polygonum aviculare. No local E2 as espécies infestantes foram: A. ludoviciana, Erysimum sp., P. aviculare, Rapistrum rugosum, C. album, Salsola kali, and Sonchus sp. Equações foram ajustadas aos dados e os efeitos das densidades das espécies daninhas foram calculadas em termos de densidade interferidora total (DIT). Regressões lineares múltiplas indicaram que apenas

1 Recebido para publicação em 12.8.2009 e na forma revisada em 15.6.2010.

2 Gorgan University of Agricultural Science and Natural resources, Department ofAgronomy, Gorgan, Iran, <gherekhloo@yahoo.com>; ${ }^{3}$ University of Tehran, Faculty of agriculture, Department of Agronomy, Karaj-Tehran, Iran, <shnoroozi@ut.ac.ir>, dmazaher@ut.ac.ir>, $<$ mrghanad@ut.ac.ir>, respectively; ${ }^{4}$ Ferdowsi University of Mashhad, Faculty of agriculture, Department of Agronomy, Mashhad, Iran, <alighanbari36@yahoo.com>; ${ }^{5}$ Universidade Federal do Rio Grande do Sul - UFRGS, Porto Alegre, Brazil, <ribas.vidal@ufrgs.br>; ${ }^{6}$ University of Cordoba, Campus of Rabanales, Cordoba, Spain, <qelpramr@uco.es>. 
A. Iudoviciana, Convolvulus spp. e C. album, em $E 1 ;$ e A. ludoviciana, S. kali, and R. rugosum, em E2, tiveram efeito significativo sobre a redução da produção de trigo. NDE foi 5,23 DIT em E1 e 6,16 DIT em E2, os quais foram equivalentes a 5 plantas $\mathrm{m}^{-2}$ de A. ludoviciana ou 12 plantas $m^{-2}$ de Convolvulus spp. ou 19 plantas $m^{-2}$ de C. album em E1; e 6 plantas $m^{-2}$ de A. Iudoviciana, 13 plantas $m^{-2}$ de S. kali e 27 plantas $m^{-2}$ de $\boldsymbol{R}$. rugosum em E2. Simulações de NDE utilizando vários preços de grãos de trigo e custos de controle de plantas daninhas permitiram comparar os experimentos sugerindo que uma cultura mais competitiva no local E1 em relação a E2 foi a causa da competitividade mais baixa das infestantes no primeiro local.

Palavras-chave: interferência, competição, rendimento de grãos, regressões matemáticas.

\section{INTRODUCTION}

Winter wheat (Triticum aestivum) is one of the most important agronomic crops in the world. Weed competition for water, nutrients and light reduces wheat grain yield. Weed density is one of the most important factors in competition. Wild oat reduced the wheat biomass and number of tillers per plant and per area (Balyan et al., 1991). Weed control methods increase the cost of wheat production; thus, the estimation of crop yield losses due to weed interference and the determination of weeds' economic damage threshold are important components for a dynamic decision support in integrated weed management.

The bioeconomic models to help the decision-making process for weed management have been benefit from the use of postemergence herbicides. The selection of weed control strategies can be decided according to the weed species present in the area, and can be used only when a certain weed density has emerged. The weed economic threshold is the weed population at which the cost of control is equal to the crop value increase of the present weeds control (O’Donovan, 1991; Baziramakenga \& Leroux, 1998; Weaver \& Ivany, 1998; Pester et al., 2000).

Most weed economic thresholds levels are reported as a fixed number of plants, and are affected by several factors related to the weed, like species, density and time of emergence; related to the environment and its management; and related to the crop, like its variety and arrangement in the area (Oliver 1988; O’Donovan, 1991; Cardina et al., 1995; O’Donovan \& Blackshaw, 1997; Baziramakenga \& Leroux 1998; Weaver \& Ivany, 1998; Pester et al., 2000). Usually many of these factors change from one study to another, making comparisons and recommendations difficult to be made. For instance, the economic threshold of wild oat in wheat was estimated between 3 to 30 and 8 to 12 plants $\mathrm{m}^{-2}$, in the USA and Great Britain, respectively (Cousens, 1987). We have hypothesized that a complementary economic simulation including the crop grain prices, and the cost of weed control, would be necessary to compare the experiments and to help predicting recommendations for farm situations.

Furthermore, most of the studies evaluate the interference between a single weed species and the crop, whereas in the field situation there are several weed species that could reduce crop yield. Therefore, most of these studies have not had an important role in control decision-making (Swinton et al., 1999). The objectives of this study were: 1) to evaluate the effect of multispecies weed competition on wheat yield and its components, 2) to determine the economic threshold of weeds in wheat crop using regression equations, and 3) to evaluate the impact of crop prices and weed control costs on weed economic thresholds.

\section{MATERIALS AND METHODS}

Two field experiments were conducted in 2002 in two sites in Iran: at the Agricultural Research Station of Ferdowsi University of Mashhad (lat $36^{\circ} 18^{\prime} \mathrm{N}$, long $59^{\circ} 36^{\prime} \mathrm{E}$ ) as E1, and on the fields of Shirvan's Agricultural College (lat $33^{\circ} 24^{\prime} \mathrm{N}$, long $57^{\circ} 54^{\prime} \mathrm{E}$ ) as E2. A $15 \times 50 \mathrm{~m}$ plot of a 15-ha wheat field in E1 and a $15 \times 50 \mathrm{~m}$ plot of a 28-ha wheat field in E2 were selected as experimental sites. The experimental areas were previously cropped 
with tomato in E1, and with wheat, barley and sugar beet in E2. These areas were managed like all other parts of the fields, except that these areas were not treated with herbicides. Wheat seeds variety Kascogen in E1 and Navid in E2 were seeded on November, 2001. The fields were fertilized with $250 \mathrm{~kg} \mathrm{ha}^{-1}$ with triple super phosphate at planting time, and with $150 \mathrm{~kg} \mathrm{ha}^{-1}$ area twice after the crop emergence: at the end of tillering and at the beginning of shooting stages.

At the beginning of the shooting stage, 30 locations were sampled using $50 \times 50 \mathrm{~cm}$ squares. The assessments included number of wheat plants and tillers and number of weeds (each species separately), without destroying the plants. At the end of the growth season, all the wheat plants in the sampled square were harvested and the number of plants, the seed weight and the total biomass were measured. Regression model was used to determine the relative fractions of intraspecific competition (Equation 1):

$$
1 / W=b_{c o}+b_{c w 1} N_{w 1}+\ldots+b_{c w i} N_{w i}
$$

where $W$ is the biomass or yield per wheat plant, $b_{c o}$ is the interception of the regression equation, $b_{c w i}$ is the inter-specific competition of wheat and weed species $i$, and $N_{w i}$ is the density of the $i_{t h}$ weed species. Through Equation 1, a weed species was considered to be effective when its inter-specific competition coefficient was statistically significant.

The coefficients for interspecific competition was converted into the competitive index values called Total Competitive Load (TCL) by dividing it by the largest $b_{c w i}$ (that of the most competitive weed) (Equation 2):

$$
T C L=w_{i}+b_{c w 1} / b_{c w i} w_{1}+\ldots+b_{c w n} / b_{c w i} w_{n}
$$

where $w_{i}$ is the density of the most competitive weed, $b_{c w 1}$ is the coefficient associated with the weed species 1 , and $b_{c w n}, w_{n}$ are the coefficients of the other effective weeds.

The percentage of yield loss $(Y L)$ of each infested plot was calculated by Equation 3:

$$
Y L(\%)=\frac{\left(Y_{w f}-Y\right)}{Y_{w f}} \times 100
$$

where $Y_{w f}$ is the grain yield in weed-free plots, and $Y$ is the grain yield from each infested plot.

The relationship of the TCL and $Y L(\%)$ was estimated by the two-parameter hyperbolic model (Rizzardi et al., 2003) (Equation 4), or using the first linear segment method proposed by Vidal et al. (2004).

$$
Y L(\%)=\frac{I(T C L)}{1+\frac{I(T C L)}{A}}
$$

From Equation 4, I represents the effect of each unit of $T C L$ on the $Y L(\%)$, and the parameter $A$ represents the maximum asymptote for the $Y L(\%)$ curve.

The impact of the crop prices and herbicide costs on weed economic threshold density according to $T C L$ was estimated by using the method proposed by Vidal et al. (2004).

\section{RESULTS AND DISCUSSION}

The weeds present on location E1 were: Avena ludoviciana, Chenopodium album, Solanum nigrum, Stellaria holosea, Fumaria sp., Polygonum aviculare, Sonchus sp., and Convolvolus spp. The weeds on location E2 were: A. ludoviciana, Erysimum spp., P. aviculare, Rapistrum rugosum, C. album, Salsola kali, and Sonchus spp. The regression model using stepwise procedure indicated that only A. ludoviciana; Convolvulus spp., and C. album on location E1, and A. ludoviciana, S. kali and $R$. rugosum on location E2 reduced wheat yield significantly (data not shown).

\section{Weed economic threshold}

As weed density increased, wheat seed yield decreased hyperbolically (Figure 1). At the location E1, the economic threshold of effective weeds was $5.23 \mathrm{TCL}$, which was equivalent to 5.23 plants $\mathrm{m}^{-2}$ of $A$. ludoviciana, or 12.20 plants $\mathrm{m}^{-2}$ of Convolvulus spp., or 9.65 plants $\mathrm{m}^{-2}$ of C. album. At this experimental site, the crop grain yield was $800 \mathrm{~g} \mathrm{~m}^{-2}$ with only $5 \mathrm{TCL}$. However, as the TCL increased to 75 plants, the crop grain yield decreased to $500 \mathrm{~g} \mathrm{~m}^{-2}$ (Figure 1-E1).

At the location E2, the economic threshold of effective weeds was $6.16 \mathrm{TCL}$, which was 
equivalent to 6.16 plants $\mathrm{m}^{-2}$ of $A$. ludoviciana, or 13.02 plants $\mathrm{m}^{-2} S$. kali, or 27.80 plants $\mathrm{m}^{-2}$ $R$. rugosum. At this site, the crop grain yield was estimated to $700 \mathrm{~g} \mathrm{~m}^{-2}$ with only $5 \mathrm{TCL}$. However, as the TCL increased to 82 plants, the crop grain yield decreased to $400 \mathrm{~g} \mathrm{~m}^{-2}$ (Figure 1-E2).

\section{Effect of weeds on wheat yield components}

The increase in weed density reduced the number of fertile tillers of wheat plants in both locations of study (Figure 2). The number of fertile tiller was 550 and 518 with only 10 TCL at locations E1 and E2, respectively. However, as TCL increased to 40 plants, the number of
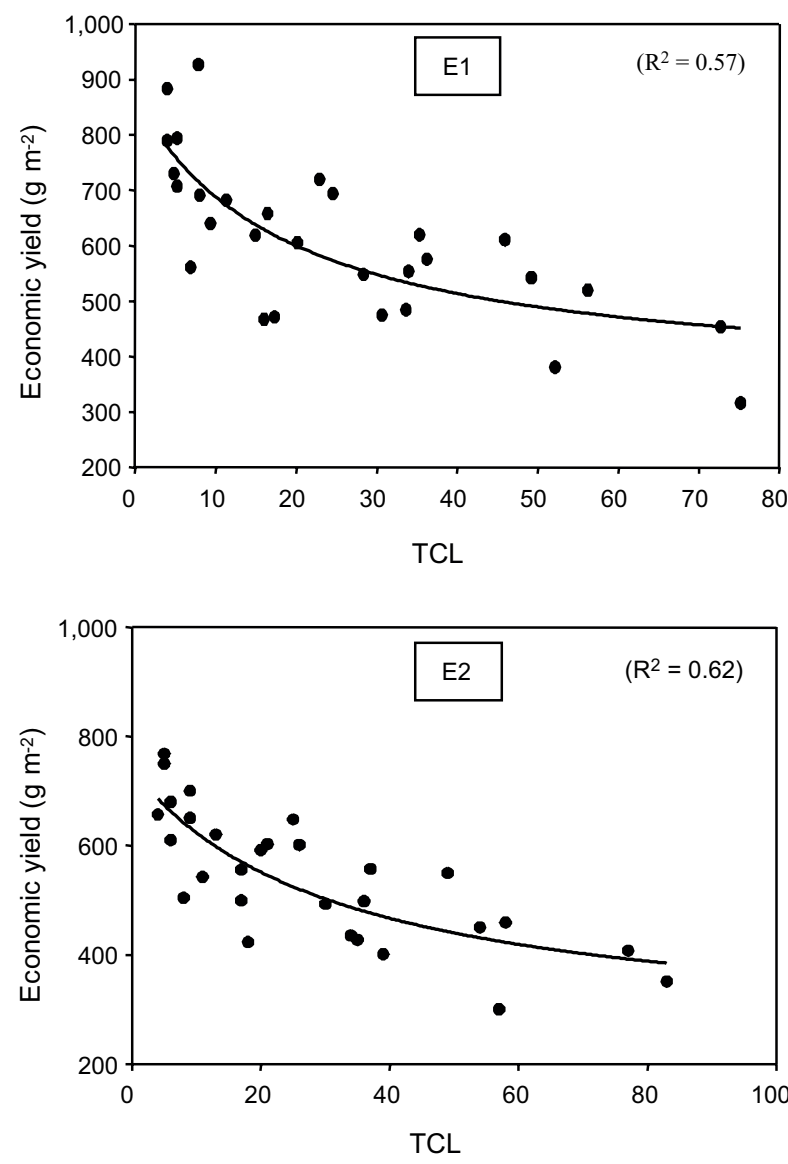

Figure 1 - Relationship between wheat yields and weed density based on the total competitive load (TLC) on two sites in Iran: Mashhad (E1): Y=872.1824 (1-((3.2427*TCL) / 100(1+ (3.2427*TCL)/60.1988))), and Shirvan (E2): $\mathrm{Y}=741.727$ (1$((2.0799 * \mathrm{TCL}) / 100(1+(2.0799 * \mathrm{TCL}) / 66.6733)))$. fertile tiller decreased to 425 and $364 \mathrm{~m}^{-2}$ (Figure 2).

The number of wheat seeds per $\mathrm{m}^{2}$ was considered as an indicator of the effect of weed competition on wheat grain yield. In this study, the increasing weed density reduced the wheat seed per $\mathrm{m}^{2}$ (Figure 3 ). The number of seeds was of 16,000 and 16,900 per $\mathrm{m}^{2}$ with only $10 \mathrm{TCL}$ at locations $\mathrm{E} 1$ and $\mathrm{E} 2$, respectively. However, as TCL increased to 40 plants, the number of seeds decreased to 12,250 and 12,000 per $\mathrm{m}^{2}$, respectively (Figure 2 ).

TCL had no effect on harvest index and kernel weight of wheat (data not shown). There was no correlation between TCL and this component of wheat yield.
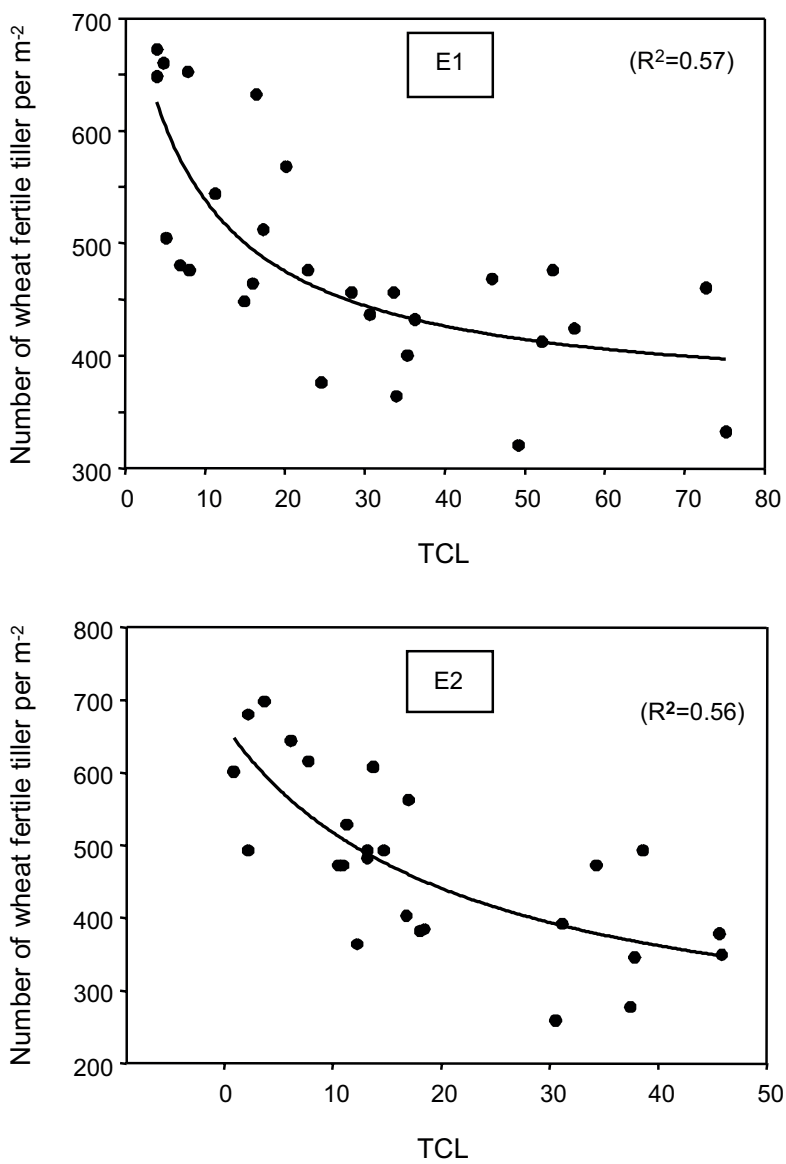

Figure 2 - Relationship between total competitive load (TCL) and number of fertile tiller on two sites inIran: Mashhad (E1): $\mathrm{Y}=747.47\left(1-\left(\left(6.055^{*} \mathrm{TCL}\right) / 100\left(1+\left(6.055^{*} \mathrm{TCL}\right) / 52.49\right)\right)\right)$ and Shirvan (E2): Y=666.81 (1- ((3.2601*TCL) / 100(1+ (3.2601*TCL)/ 70.34))). 

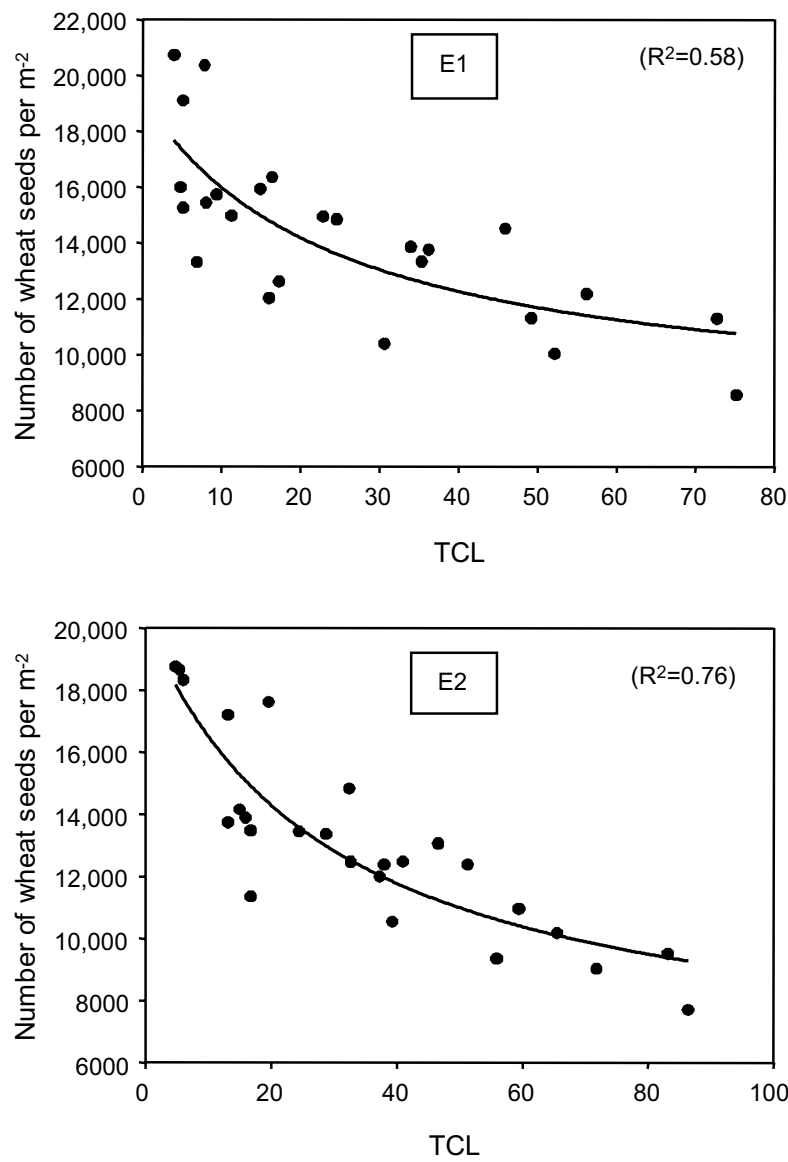

Figure 3 - Relationship between total competitive load (TCL) and number of seed per unit area on two sites in Iran: Mashhad (E1): Y=19261.7 (1- ((2.39*TCL) / 100(1+ (2.39*TCL) / 58.69))) and Shirvan (E2): Y=20619.45 (1$((2.81 * \mathrm{TCL}) / 100(1+(2.81 * \mathrm{TCL}) / 69.25)))$.

\section{The impact of the crop prices and of herbicide costs}

The wheat grain prices have been increasing steadily during the past decade. The crop values used to make the simulations started from E\$ $0.10 \mathrm{~kg}^{-1}$ to an exaggerated $\mathrm{E} \$ 0.25 \mathrm{~kg}^{-1}$, from extrapolate results to a worst-case price scenario. The cost of weed management used for the simulations ranged from $\mathrm{E} \$ 10.00$ to $\mathrm{E} \$ 20.00$. The results for the simulation in each site are presented in Figures 4 and 5 .

In site E1, the values of weed economic threshold ranged from 2 to 11 plants per $\mathrm{m}^{2}$; whereas in site E2, these values ranged from 2 to 20 plants per $\mathrm{m}^{2}$. In both places, the weed economic threshold was reduced with the

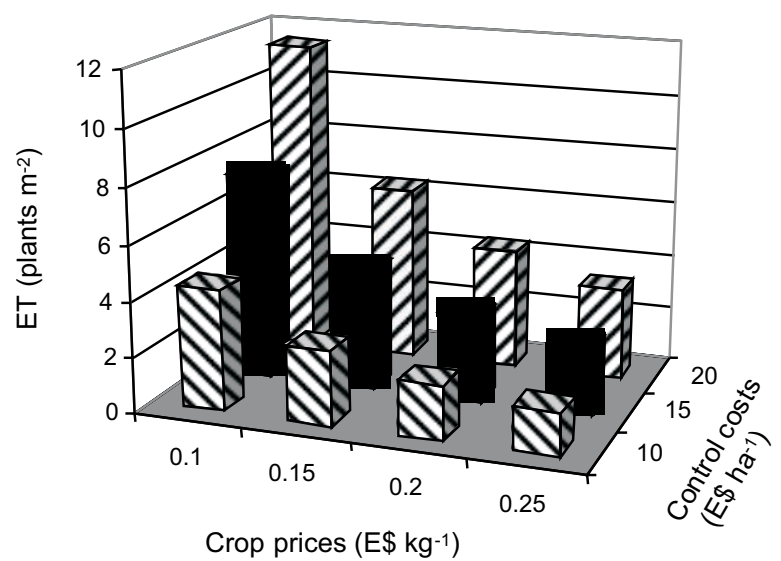

Figure 4 - Weed economic thresholds (ET), expressed as total competitive load, at Mashhad (E1), Iran, simulated according to several crop prices and weed control costs.

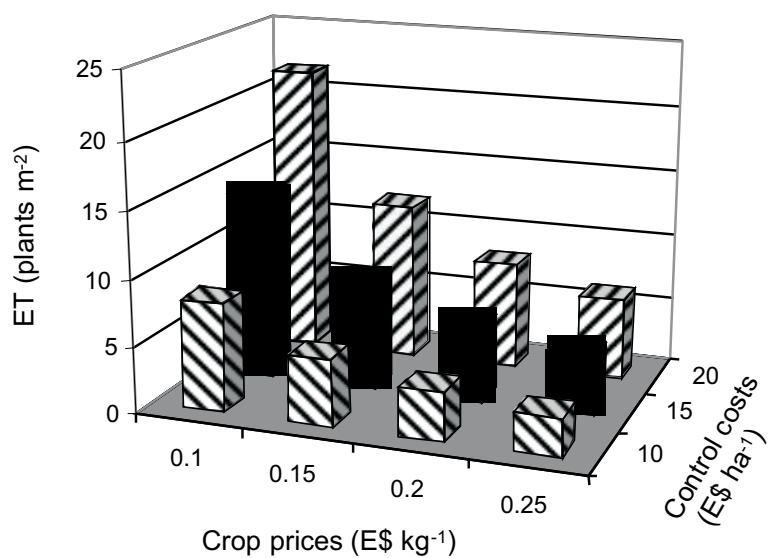

Figure 5 - Weed economic thresholds (ET), expressed as total competitive load, at Shirvan (E2), Iran, simulated according to several crop prices and weed control costs.

increment of the crop grain prices and with the reduction of weed management costs (Figures 4 and 5).

This work was conducted in order to evaluate multispecies weed competition and economic threshold on wheat crop using regression equations. It was possible to calculate the TCL from the weed species composition on the community and to indicate the effective weeds on the wheat grain yield in each site (Figure 1).

Despite the fact that several weed species were present in each experimental location, statistical procedures allowed the estimation of an overall weed competitive ability with only 
three plant species in each location. In site $\mathrm{E} 1$, the grain yield of the weed-free crop was $872 \mathrm{~g} \mathrm{~m}^{-2}$. Wheat crop with more competitive ability may have helped reducing the TCL of the area when compared to site E2, in which weed-free grain yield was only $741 \mathrm{~g} \mathrm{~m}^{-2}$ (Figure 1). However, another interpretation of these results is that other differences among experiments may have caused the differences observed. In fact, the impact of weed interference on crop yield have been shown to be affected by several factors, such as potential crop yield (Oliver, 1988; O'Donovan, 1991; O'Donovan \& Blackshaw, 1997; Baziramakenga \& Leroux 1998), environmental factors, including temperature, amount and time of rainfall (Pester et al., 2000), tillage system (Cardina et al., 1995), weed density and species (Weaver \& Ivany, 1998; Oliver, 1988), and date of weed emergence in relation to crop emergence (Oliver, 1988).

The variation on many of these factors from site E1 to site E2 makes it difficult to compare both experiments. The complementary economic analysis using simulations of weed economic thresholds at several crop grain prices and weed control costs has helped interpreting the results from both experiments (Figures 4 and 5). This approach has been susscessfully used in Brazil do determine economic thresholds for Echinochloa spp., in rice (Galon et al., 2007), Brachiaria plantaginea, Bidens pilosa, B. subalternans, Euphorbia heterophylla, Ipomoea ramosissima and Sida rhombifolia in soybean (Fleck, 1996; Fleck et al., 2002; Rizzardi et al., 2003, Rizzardi et al., 2004), and Brachiaria plantaginea in corn (Vidal et al., 2004).

In location $\mathrm{E} 1$, the crop had a yield potential of $870 \mathrm{~g} \mathrm{~m}^{-2}$, which was $15 \%$ superior to the crop in location E2, probably due to increased competitive ability or better resources capture. The results of the simulations of the weed economic threshold indicated that the weed densities increased almost two-fold with a $15 \%$ reduction of crop yield potential, from site 1 to site 2 (Figures 4 and 5). Similar trend of increased crop density reducing weed competitive ability was found also by others researchers (Carlson \& Hill, 1985; Vidal et al., 2004).

Planta Daninha, Viçosa-MG, v. 28, n. 2, p. 239-246, 2010
The analysis of the yield components affected by weed competition indicated that as the weed density increased, the number of fertile tiller decreased in both locations (Figure 2). Likewise, as weed density increased, the number of wheat seed $\mathrm{m}^{-2}$ decreased (Figure 3). These results are in agreement to several others from the literature. When the weed was wild oat, increased weed density reduced the number of fertile tiller in wheat (Martin \& Field, 1988; Balyan et al., 1991).

Apparently, the general theory is that the effect of weed competition on cereals grain yield is caused by the reduction on number of tillers and fertile tiller per plant and per unit area, as previously reported by Morishita \& Thill (1988) in wild oat (Avena fatua) competition with barley; by Hashem et al. (1998) in ryegrass (Lolium rigidum) competition with winter wheat; and by Bhaskar \& Vyas (1988) in Chenopodium album competition with wheat.

The relevance of this work is that weed economic threshold was determined early in the growing season and considered all effective weeds in the experiment. The estimated weed economic threshold had high reliability because the experiments were performed in farmers' fields, with all appropriated conditions to crop production. Also, the additional simulation of weed economic threshold in bestand worst-case scenarios can help comparing experiments and making recommendations for weed management.

One limitation of the results is the fact that the economic threshold model is a bioeconomic model which assumes that weeds are regularly spaced. Because weed distribution can impact sampling procedures as well as the decisions for weed management (i.e., herbicide application), it is advisable to increase the number of samples in order to decrease the effect of uneven distribution of weeds, and increase the experiment accuracy (VanGessel et al., 1995), mainly when weeds are unevenly distributed in the fields. Another limitation of weed economic threshold is that the estimatives are not reliable when the competitor species are capable of decreasing the grain quality, or when the species is first invading a field and can form extensive seed bank, or reproduce vegetatively. Several 
authors point out that once the weed density in the area reaches the economic threshold, the herbicide rate to be chosen should be enough to control all the plants in the field, avoiding the selection of resistant biotypes (Trezzi et al., 2005; Vidal et al., 2007).

Results of this research showed that the weed economic threshold can be evaluated in a mixed species population and in a real life farm situation. The comparison among experiments can be more reliable using simulations of the weed economic threshold with different crop grain prices and weed control costs. In general, the weed economic threshold is reduced with the increment of the crop grain prices and with the reduction of the costs of weed management. Avena ludoviciana was more competitive to the wheat crop than Convolvulus spp., Chenopodium album, Salsola kali, or Rapistrum rugosum.

\section{ACKNOWLEDGEMENTS}

The authors wish to acknowledge the financial support afforded by Iranian Research Council (National Research Project No: 1507) for the implementation of this project. Also CNPQ (Brazilian Research Council), for the support to the last author.

\section{LITERATURE CITED}

BALYAN, R. S. et al. Competitive ability of winter wheat cultivars with wild oat (Avena ludoviciana). Leed Sci., v. 39, n. 2, p. 154-158, 1991.

BAZIRAMAKENGA, R.; LEROUX, G. D. Economic and interference threshold densities of quackgrass (Elytrigia repens) in potato (Solanum tuberosum). Leed Sci., v. 46, n. 2, p. 176-180, 1998.

BHASKAR, A.; VYAS, K. G. Studies on competition between wheat and Chenopodium album L. Weed Res., v. 26, n. 1, p. $53-58,1988$

CARDINA, J.; REGNIER, E.; SPARROW, D. Velvetleaf (Abutilon theophrasti) competition and economic threshold in conventional- and no-tillage corn (Zea mays). Weed Sci., v. 43, n. 1, p. $81-87,1995$.

CARLSON, H. L.; HILL, E. Wild oat competition with spring wheat: Plant density effects. Weed Sci., v. 33, n. 2, p. 178-181, 1985.
COUSENS, R. Theory and reality of weed control thresholds Plant Protect. Quart., v. 2, n. 1, p. 13-20, 1987.

FLECK, N. G. Interferência de papuã (Brachiaria plantaginea) com soja e ganho de produtividade obtido através do seu controle. Pesq. Agropec. Gaúcha, v. 2, n. 1, p. 63-68, 1996.

FLECK, N. G.; RIZZARDI, M. A.; AGOSTINETTO, D. Nível do dano econômico como critério para tomada de decisão no controle de guanxuma em soja. Planta Daninha, v. 20 , n. 3 , p. $421-429,2002$

GALON, L. et al. Níveis de dano econômico para decisão de controle de capim-arroz (Echinochloa spp.) em arroz irrigado (Oryza sativa). Planta Daninha, v. 25, n. 4, p. 709, 718, 2007.

HASHEM, A.; RADOSEVICH, S. R.; ROUSH, M. L. Effect of proximity factors on competition between winter wheat (Triticum aestivum) and italian ryegrass (Lolium multiflorum). Weed Sci., v. 46, n. 2, p. 181-190, 1998.

MARTIN, R. J.; FIELD, R. J. Influence of time of emergence of wild oat on competition with wheat. Weed Res., v. 28, n. 2, p. 111-116, 1988.

MORISHITA, D. W.; THILL, D. C. Factors of wild oat interference on spring barley growth and yield. Weed Sci., v. 36, n. 1, p. $37-42,1988$.

O’DONOVAN, J. T. Quack grass (Elytrigia repens) interference in Canola (Brassica compestris). Weed Sci. v. 39 , n. 3, p. 397-401, 1991

O'DONOVAN, J. T.; BLACKSHAW, R. E. Effect of volunteer barley (Hordeum vulgare L.) interference on field pea (Pisum sativum L.) yield and profitability. Weed Sci., v. 42 , n. 2, p. $249-255,1997$

OLIVER, L. R. Principles of weed threshold research. Weed Technol., v. 2, n. 4, p. 398-403, 1988.

PESTER, T. A. et al. Secale cereale interference and economic thresholds in winter Triticum aestivum. Weed Sci., v. 48, n. 6, p. $720-727,2000$.

RIZZARDI, M. A.; FLECK, N. G.; AGOSTINETTO, D. Nível de dano econômico como critério para controle de picão-preto em soja. Planta Daninha, v. 21, n. 2, p. 273$282,2003$.

RIZZARDI, M. A. et al. Interferência de populações de Euphorbia heterophylla e Ipomoea ramosissima isoladas ou em misturas sobre a cultura da soja. Planta Daninha, v. 22, n. 1, p. $29-34,2004$ 
SWINTON, S. M. et al. Estimation of crop yield loss due to interference by multiple weed species. Weed Sci., v. 42, n. 1, p. 103-109, 1994.

TREZZI, M. M. et al. Multiple resistance to acetolactate synthase and protoporphyrinogen oxidase inhibitors in Euphorbia heterophylla biotypes. J. Environ. Sci. Health., v. 40, n. 1, p. 101-109, 2005

VANGESSEL, M. J. et al. Influence of weed density and distribution on corn (Zea mays) yield. Weed Sci., v. 43, n. 2, p. $215-218,1995$
VIDAL, R. A. et al. Nível de dano econômico de Brachiaria plantaginea na cultura de milho irrigado. Planta Daninha, v. 22, n. 1, p. 63-69, 2004.

VIDAL, R. A. et al. Glyphosate resistant biotypes of wild poinsettia (Euphorbia heterophylla (L.)) and its risk analysis on glyphosate-tolerant soybeans. J. Food Agric. Environ., v. 5 , n. 2 , p. $265-269,2007$.

WEAVER, S. E.; IVANY, J. A. Economic threshold for wild radish, wild oat, hemp nettle, and corn spurry in spring barley. Canadian J. Plant Sci., v. 78, n. 2, p. 357-361, 1998 